\title{
HORMONE PROFILES AND THEIR RELATION WITH MENSTRUAL CYCLES IN PATIENTS UNDERGOING HEMODIALYSIS
}

\author{
Deniz Cemgil ARIKAN ${ }^{1}$, Serpil BOZKURT ${ }^{2}$, Ilker ARIKAN ${ }^{3}$, Emre TURGUT $^{4}$
}

${ }^{1}$ Department of Obstetrics Gynecology, Faculty of Medicine, Sutcu Imam University, Kahramanmaraş, Turkey

2 Department of Obstetrics Gynecology, Faculty of Medicine, Maltepe University, Istanbul, Turkey

${ }^{3}$ Department of Obstetrics Gynecology, Faculty of Medicine, Karaelmas University, Zonguldak, Turkey

${ }^{4}$ Department of Obstetrics and Gynecology, Istanbul Education and Research Hospital, Istanbul, Turkey

\begin{abstract}
SUMMARY
Objective: To investigate the etiology of menstrual disorders among patients undergoing hemodialysis due to chronic renal failure by assessing menstrual history, serum hormone levels and other biochemical factors.

Material and methods: Thirty patients undergoing hemodialysis and 30 healthy women at reproductive age were enrolled in our study. Demographic characteristics, hormonal and biochemical data, sonographically measured endometrial thickness values of the subjects were compared. In addition, the present and the pre-hemodialysis menstrual pattern of the patients undergoing hemodialysis were recorded. The hormonal, hematological and biochemical data of the patients were compared according to their menstrual patterns.

Results: No statistical significance was seen between age, BMI, gravida, parity, abortion and curettage among groups $(p>0.05)$. Hemoglobin and hematocrit levels were significantly lower in the hemodialysis group than in the control $(p<0.05)$. Although serum FSH levels were higher and estradiol levels were lower in the hemodialysis group, these differences were not statistically significant ( $p>0.05)$. Mean serum LH and prolactin levels were significantly higher in the hemodialysis group compared to the control $(p<0.05)$. No statistically significant difference was noted for endometrial thickness between the groups ( $p>0.05$ ). Serum LH and prolactin levels were higher and serum FSH, estradiol and TSH levels were lower in patients who developed amenorrhea after hemodialysis treatment when compared to non-amenorrheic subjects. However, these differences were not statistically significant $(p>0.05)$. Discussion: The most important factor in the etiology of menstrual disorders seen in chronic renal failure patients was high serum LH and prolactin levels. Hemodialysis is a successful treatment that extends life expectancy and ameliorates the hypothalamo-pituitary-ovarian axis in chronic renal failure patients.
\end{abstract}

Key words: chronic renal failure, hemodialysis, menstrual disturbances, hormone profiles

Journal of Turkish Society of Obstetrics and Gynecology, (J Turk Soc Obstet Gynecol), 2011; Vol: 8 Issue: 1 Pages: $32-9$

ÖZET

\section{HEMODIYYLIZ HASTALARINDA HORMON PROFILLERI VE MENSTRUEL SÍKLUSLA İLIȘKISİ}

Amaç: Kronik böbrek yetmezliği (KBY) nedeniyle hemodiyalize giren hastaların menstrüel öykü ile birlikte, hormon seviyelerine ve diğer biyokimyasal faktörlerine bakarak, menstrüel bozuklukların altında yatan mekanizmayı araştırmak. Gereç ve yöntemler: Çalışmamıza, reprodüktif yaş grubunda, hemodiyalize giren 30 hasta ile 30 sağlıklı kadın alındı. Olguların

Address for Correspondence: Yard. Doç. Dr. Deniz Cemgil Arıkan. Sütçü İmam Üniversitesi, Kadın Hastalıkları ve Doğum Anabilim Dalı, 46050 Kahramanmaraş, Turkey Phone: +90 (505) 8022847 e-mail: drdenizarikan@hotmail.com

Received: 02 February 2010, revised: 12 August 2010, accepted: 21 September 2010, online publication: 15 December 2010 
demografik özellikleri, hormon profilleri, biyokimyasal değerleri ve ultrasonografi ile ölçülen endometriyal kalınlıkları karşılaştırıldi. Ayrıca hemodiyaliz hastalarının diyaliz programına alınmadan ve alındıktan sonraki detaylı menstrüel ve jinekolojik öyküleri alınd, menstrüasyon şekillerine göre hormonal, hematolojik ve biyokimyasal değerleri karşılaştırıldı. Bulgular: Hasta ve kontrol grubu arasında yaş, VKI, gravida, parite, abortus ve küretaj açısından istatiksel olarak anlamlı bir fark tespit edilmedi ( $p>0,05)$. Hemodiyaliz grubunda kontrol grubuna göre hemoglobin ve hematokrit değerleri istatistiksel olarak anlamlı derecede düşük bulundu $(p<0,05)$. Hemodiyaliz grubunda FSH değerleri daha yüksek, östradiol değerleri daha düşük bulunmasına rağmen her iki grup arasında istatistiksel olarak anlamlı bir farklılık yoktu (p>0,05). Hasta grubunda LH ve prolaktin değerlerinin ortalaması kontrol grubuna göre istatistiksel olarak anlamlı derecede daha yüksekti $(p<0,05)$. Hasta ve kontrol grubu arasında ultrasonografik olarak ölçülen endometrial kalınlık ortalama değerleri bakımından istatistiksel olarak anlamlı bir farklılık yoktu ( $>>0,05)$. Hemodiyaliz sonrası amenore gelişen hastaların LH ve prolaktin değerleri amenore gelişmeyen hastalara göre daha yüksek, FSH, östradiol ve TSH değerleri ise daha düşük olarak saptand. Fakat bulunan bu fark istatistiksel olarak anlamlı değildi $(p>0,05)$. Sonuç: KBY hastalarında görülen menstrüel bozuklukların etyolojisindeki en önemli faktör, bu hastalarda saptanan LH ve prolaktin yüksekliğidir. Hemodiyaliz bu hastaların yaşam sürelerini uzatan ve hipotalamus-hipofiz-over aksının düzelmesini să̆layan başarılı bir tedavidir.

Anahtar kelimeler: hemodiyaliz, hormon profilleri, kronik böbrek yetmezliği, menstrüel bozukluklar

Türk Jinekoloji ve Obstetrik Derneği Dergisi, (J Turk Soc Obstet Gynecol), 2011; Cilt: 8 Sayl: 1 Sayfa: 32- 9

\section{INTRODUCTION}

Reproductive disorders are common in adult patients from both sexes with end-stage renal disease ${ }^{(1)}$. It has been reported that in female patients hypothalamichypophysial regulation is disrupted due to increase in growth hormone and prolactin levels as a result of uremia, and that libido decreases in women as in men ${ }^{(2-7)}$.

In women with chronic renal failure (CRF), since the LH surge stimulated by estrogen does not happen, anovulation, menstrual disorders and infertility develops ${ }^{(8)}$. Furthermore, in uremic patients even if gonadotropin levels increase following ovarian stimulation with clomiphene, there is no increase in estrogen levels. This supports the existence of ovarian resistance against stimulation(2). Studies have shown that $50-100 \%$ of patients have amenorrhea ${ }^{(9)}$, and among the patients that have periods 50 to $80 \%$ have hypermenorrhea, menometrorrhagia, or oligomenorrhea $(5,10,11)$. In addition, while amenorrhe was detected in women with high prolactin, regular menstruation was reported in women with the lowest level of prolactin(5). Normal menstrual cycles and ovulation might be seen with the start of hemodialysis $(11,12)$.

As the length of life increase with the emerging treatment options, especially in women, we started to face of the problems related to reproductive system more frequently. In this study, we aimed to investigate the mechanism underlying the menstrual disorders by looking at menstrual histories of chronic renal failure patients undergoing hemodialysis, along with hormone levels and other biochemical factors.

\section{MATERIALS AND METHODS}

In our study, 30 patients undergoing hemodialysis (patient group), 30 control patients (control group) and a total of 60 patients that agreed to participate in the study were included. Before the study was started approval was provided by the ethics committee of SSK Istanbul Training and Research Hospital. Patients in the reproductive age group were included in order to minimize the changes of the menstrual and hormonal parameters due to age. 30 patients that undergo hemodialysis in SSK Istanbul Training and Research Hospital Hemodialysis Unit and Özgözükara Hemodialysis Center for a minimum of 12 months due to chronic renal failure, who have less than $5 \mathrm{ml} /$ minute of creatinine clearance, and who are in the reproductive age group (15-45 year) were included. Patients that had gynecological operation such as hysterectomy and/or oophorectomy, that were exposed to any cranial operation or intervention, patients that had any known endocrine and / or gynecologic disease, use a hormonal drug or oral contraceptives for contraception, are not conscious enough to give the 
story were excluded from the study.

Bicarbonate dialysis was performed in all the patients in the study and during the dialysis low-molecular-weight heparin (Fragminin, Fraxiparine) was used for the prevention of clotting of the blood. Phos-ex $3 \mathrm{X} 1$ or $3 \times 2$ oral tablets, Vitamin D3, B-complex vitamins were used as calcium supplements and in order to bind phosphorus, folic acid was used in megaloblastic anemia and erythropoietin was used in patients that have a hematocrit level less than $30 \%$, and patients with albumin levels below $4 \mathrm{~g} / \mathrm{dL}$ were receiving essential amino acids.

Nephrological stories of patients, a detailed menstrual history before and after the dialysis program were obtained, various demographic characteristics (age, body mass index (BMI), gravidity, parity, abortion, curettage, duration of dialysis, their causes and the number of weekly dialysis) were questioned and recorded. Whether they had amenorrhea or not after the dialysis, duration of amenorrhea, and usage of any method of contraception were asked, the existence of galactorrhea and hirsutism were assessed.

Venous blood was obtained from the hemodialysis patients on the 5th day of menstruation (if they would have dialysis on the 5th day of menstrual cycle just before the dialysis) for hormonal and biochemical studies. Hemoglobin, hematocrit, urea, creatinine, sodium, potassium, calcium, AST, ALT, phosphorus, fasting blood glucose and FSH, LH, estradiol, TSH, and prolactin levels among the hormones were measured.

30 women that resorted to SSK Istanbul Training Hospital, II. Obstetrics and Gynecology outpatient clinic, who are in the reproductive age group (15-45 years), have no systemic or non-hormonal disease, and have regular menses were recruited in the control group. On the $5^{\text {th }}$ day of menstruation, at 8:30 in the morning, after 12 hour fasting, venous blood was taken and biochemical and hormonal parameters were studied. The demographic characteristics of the control group (age, BMI, gravidity, parity, abortion, curettage) were also recorded.

Hemodialysis and control groups were compared in terms of all these parameters.

In the biochemistry laboratory of SSK Istanbul Teaching Hospital urea, creatinine and electrolytes were analysed using Olympus AU 5223 automated analysis device, and complete blood count analysis was performed in the Sysmex SE-9000 device models. FSH, LH, TSH and prolactin levels were evaluated in ACS 180 analysis device using electrochemiluminescence immunoassay technique. References of the biochemical laboratory were used for the interpretation of the test results. In addition, during the 8 th day of menses the endometrial thickness of all the patients undergoing hemodialysis and the control group was measured by pelvic ultrasound and compared between groups.

Hemodialysis patients were divided into four groups as amenorrheic, oligomenoreic, menorrhagic and regular according to their forms of menstruation. Hormonal, hematologic and biochemical values of patients from these four groups were compared. In this study, the patients were also divided into two groups as patients that have amonerrhea or not following the dialysis and they were compared with respect to hormonal parameters. Among the patient group in all the patients with menstrual irregularities, spontaneous menstruation was waited to perform hormonal and biochemical blood tests and no treatment was started in none of the patients.

In our study SPSS 9.0 (SPSS Inc., Chicago, Illinois) software package was used for the statistical analysis. For comparison of patient and control groups Student's t-test and MannWhitney U test were performed. Kruskal-Wallis test was used for comparison of more than two groups.

\section{RESULTS}

Demographic data and comparisons of 30 hemodialysis and 30 control patients a total of 60 patients are shown in Table I. The mean age in the patient group and control group were $34.17+6.59$ and $32.63+5.67$, respectively. There was not any statistically significant difference $(p>0.05)$ between the patients and the control group in terms of age, BMI, gravidity, parity, previous abortions and curettage.

Table I: Demographic data of hemodialysis patients and the control group.

\begin{tabular}{llllll}
\hline & \multicolumn{2}{l}{ PATIENT } & \multicolumn{2}{l}{ CONTROL } & p value \\
\hline $\begin{array}{l}\text { Age (average } \pm \text { SD) } \\
\text { BMI (average } \pm \text { SD) }\end{array}$ & 34,17 & 6,59 & 32,63 & 5,67 & 0,338 \\
GRAVIDA & 3,76 & 24,54 & 2,87 & 0,064 \\
(median (min-max)) & 1,00 & $(0,00-4,00)$ & 2,00 & $(0,00-5,00)$ & 0,815 \\
$\begin{array}{l}\text { PARITE } \\
\text { (median (min-max)) }\end{array}$ & 1,00 & $(0,00-4,00)$ & 1,00 & $(0,00-4,00)$ & 0,981 \\
$\begin{array}{l}\text { ABORTUS } \\
\text { (median (min-max)) }\end{array}$ & 0,00 & $(0,00-2,00)$ & 0,00 & $(0,00-2,00)$ & 0,139 \\
$\begin{array}{l}\text { KÜRETAJ } \\
\text { (median (min-max)) }\end{array}$ & 0,00 & $(0,00-2,00)$ & 0,00 & $(0,00-3,00)$ & 0,061 \\
\hline $\begin{array}{l}\text { BMI; body mass index } \\
\text { SD; standard deviation }\end{array}$ & & & & & \\
\end{tabular}


In the hemodialysis patients the average duration of dialysis was determined as 6.28 years (at least 1.5 years, 22 years at most), and the average number of weekly dialysis was determined as 3 .

The hematologic and biochemical values of patient and control groups are shown in Table II. Hemoglobin and hematocrit values were found significantly lower $(p<0.05)$ in the hemodialysis group compared to the control group. Sodium, potassium, urea, creatinine and phosphorus levels, on the other hand, were significantly higher $(\mathrm{p}<0.05)$ in the hemodialysis patients.

Tablo II: The hematologic and biochemical values in hemodialysis patients and the control group.

\begin{tabular}{|c|c|c|c|c|c|}
\hline & $\begin{array}{l}\text { PATIENT } \\
\text { average } \pm\end{array}$ & SD & $\begin{array}{l}\text { CONTROI } \\
\text { average } \pm\end{array}$ & SD & $\mathrm{p}$ value \\
\hline Hemoglobin (g/dL) & 10,21 & 1,10 & 12,94 & 0,74 & $0,000^{*}$ \\
\hline Hematocrit (\%) & 31,18 & 3,43 & 38,35 & 1,86 & $0,000^{*}$ \\
\hline Sodium (mmol/L) & 141,40 & 4,06 & 139,03 & 1,30 & $0,004 *$ \\
\hline Potassium $(\mathrm{mmol} / \mathrm{L})$ & 4,68 & 0,90 & 4,02 & 0,24 & $0,000^{*}$ \\
\hline BUN (mg/dl) & 155,80 & 43,07 & 25,93 & 8,60 & $0,000^{*}$ \\
\hline Creatinine (mg/dl) & 9,58 & 1,84 & 0,84 & 0,15 & $0,000^{*}$ \\
\hline Blood glucose (mg/dl) & 82,97 & 18,13 & 81,17 & 10,68 & 0,641 \\
\hline Calcium (mg/dl) & 9,56 & 1,17 & 9,53 & 0,29 & 0,881 \\
\hline Phosphorus (mg/dl) & 6,47 & 1,73 & 3,56 & 0,44 & 0,000 * \\
\hline AST (U/L) & 14,93 & 7,27 & 17,30 & 6,32 & 0,184 \\
\hline $\operatorname{ALT}(\mathrm{U} / \mathrm{L})$ & 17,57 & 10,60 & 16,80 & 6,44 & 0,736 \\
\hline
\end{tabular}

$* p<0,05$

SD; standard deviation

In Table III, hormone levels and their comparisons in the patient and control groups are presented. High levels of LH and prolactin in the patient group compared to control group were statistically significant $(\mathrm{p}<0.05)$. However, the average TSH levels were significantly higher $(\mathrm{p}<0.05)$ in the control group.

Tablo III: Hormonal values in hemodialysis Patients and the control group.

\begin{tabular}{llllll}
\hline & \multicolumn{4}{l}{ PATIENT } & \multicolumn{2}{l}{ CONTROL } & \\
& average \pm & SD & average \pm & SD & p value \\
\hline FSH $(\mathrm{mIU} / \mathrm{ml})$ & 13,96 & 26,63 & 5,44 & 3,91 & 0,088 \\
LH $(\mathrm{mIU} / \mathrm{ml})$ & 17,10 & 16,22 & 5,45 & 3,79 & $0,000^{*}$ \\
Estradiol $(\mathrm{pg} / \mathrm{ml})$ & 67,58 & 48,17 & 77,76 & 55,52 & 0,451 \\
Prolaktin $(\mathrm{ng} / \mathrm{ml})$ & 45,12 & 40,41 & 14,78 & 8,45 & $0,000^{*}$ \\
TSH $(\mathrm{uIU} / \mathrm{ml})$ & 1,66 & 0,78 & 2,84 & 3,05 & $0,046^{*}$ \\
\hline${ }^{*}<0,05$ & & & & &
\end{tabular}

SD; standard deviation

Despite the high blood levels of prolactin in the chronic hemodialysis patients, galactorrhea was detected only in $4(13 \%)$ patients. In $2(7 \%)$ patients hirsutism was detected. None of the patients in the control group had galactorrhea or hirsutism. 16 hemodialysis patients $(53 \%)$ stated that they do not use any method of contraception, 13 (44\%) patients were protected by their partner, and $1(3 \%)$ stated that they are protected with tubal ligation.

Mean values of endometrial thickness measured by ultrasonography in patient and control groups were $6.52 \pm 2.13 \mathrm{~cm}$ and $6.58 \pm 1.59 \mathrm{~cm}$, respectively $(\mathrm{p}>$ $0.05)$.

After taken into the hemodialysis program 14 hemodialysis patients (47\%) developed amenorrhea and the average duration of amenorrhea was found to be 12 months. With the hemodialysis treatment amenorrhea disappeared in 9 (64\%) of the patients, and amenorrhea continued during the study in only 5 of these patients $(36 \%)$. After the hemodialysis LH and prolactin levels in the group that developed amenorrhea were higher compared to group that did not develop amenorrhea on the other hand FSH, estradiol and TSH were lower (Table IV) $(\mathrm{p}>0.05)$.

Tablo IV: The hormone levels in hemodialysis patients that had post-amenorrhea.

\begin{tabular}{|c|c|c|c|c|c|}
\hline & $\begin{array}{l}\text { AMENOF } \\
(-)(n=16) \\
\text { average } \pm\end{array}$ & $\begin{array}{l}\text { RRHEA } \\
\text { SD }\end{array}$ & $\begin{array}{l}\text { AMENOF } \\
(+)(n=14) \\
\text { average } \pm\end{array}$ & $\begin{array}{l}\text { RRHEA } \\
\text { SD }\end{array}$ & $\mathrm{p}$ value \\
\hline FSH (mIU/ml) & 14,24 & 26,11 & 13,64 & 28,19 & 0,952 \\
\hline LH (mIU/ml) & 14,57 & 16,15 & 19,98 & 16,42 & 0,371 \\
\hline Estradiol (pg/ml) & 78,84 & 57,69 & 57,74 & 37,15 & 0,238 \\
\hline Prolactin $(\mathrm{ng} / \mathrm{ml})$ & 38,76 & 33,54 & 52,39 & 47,31 & 0,366 \\
\hline TSH (uIU/ml) & 1,83 & 0,89 & 1,47 & 0,60 & 0,213 \\
\hline
\end{tabular}

; mumber of patients

Among the hemodialysis patients 17 (57\%) of them had regular menstruation, 7 (23\%) of them had oligomenorrhea, 5 (17\%) had amenorrhea, and $1(3 \%)$ had menometrorrhagia. Among these patients the average ages in the group with regular menstruation (17 patients) and with amenorrhea (13 patients) were $34.88 \pm 7.32$ and $33.23 \pm 5.64$ years, respectively, the average duration of dialysis was $75.88 \pm 60.04$ and $74.77 \pm 23.70$ months, respectively, and there were no statistically significant difference between the two groups $(\mathrm{p}>0.05)$.

After the patients were divided into four groups according to their menstrual features, FSH, LH, 
estradiol, prolactin and TSH values are shown in Table $\mathrm{V}$. The mean estradiol levels in the group that have regular menstrual cycles were significantly higher $(p$ $<0.05)$ compared to other groups.

According to menstrual status, mean values of potassium were significantly higher $(p<0.05)$ in the amenorrhea group compared to other groups (Table VI).

\section{DISCUSSION}

In patients with end-stage renal failure that did not have an effective treatment until the 1960s, menstrual disorders leading to serious physical and emotional problems are common. In a study of 25 patients in the reproductive age group with end stage renal failure, Kawashima et al stated that $20(80 \%)$ patients developed amenorrhea with dialysis. These patients were follow- up for 3 to 66 months and showed that menstrual cycle returned in $14(70 \%)$ of the patients, while in $6(30 \%)$ of the patients amenorrhea continued(13). Morley et al reported that among the 12 hemodialysis patients 7 (58\%) of the patients developed amenorrhea; in 4 (57\%) patients amenorrhea continued after hemodialysis, and in $3(42 \%)$ patients menses returned (11). In our study in line with the literature we also showed that in a total of 30 hemodialysis patients 14 (47\%) of them developed amenorrhea after receiving the dialysis program and found that this lasted for an average of 12 months. With the hemodialysis therapy, amenorrhea seemed to disappear in the majority of these patients. During the study, only 5 of these patients (36\%) amenorrhea persisted, and in $57 \%$ of the patients regular menstruation was seen, $23 \%$ of them had oligomenorrhea, $17 \%$ of them had amenorrhea, and $3 \%$ had menometrorrhagia.

Menstrual changes and blood hormone levels might

Tablo $\mathrm{V}$ : Menstruation by type of hormone levels in hemodialysis patients.

\begin{tabular}{|c|c|c|c|c|c|c|c|c|}
\hline & \multicolumn{2}{|l|}{$\begin{array}{l}\text { Regular } \\
(n=17)\end{array}$} & \multicolumn{2}{|c|}{$\begin{array}{l}\text { Oligomenorrhea } \\
(n=7)\end{array}$} & \multicolumn{2}{|c|}{$\begin{array}{l}\text { Amenorrhea } \\
(n=5)\end{array}$} & \multicolumn{2}{|c|}{$\begin{array}{l}\text { Menometrorrhagia } \\
(n=1)\end{array}$} \\
\hline & average \pm & SD & average \pm & SD & average \pm & $\mathrm{SD}$ & average & $\mathrm{p}$ value \\
\hline FSH (mIU/ml) & 6,75 & 9,12 & 5,86 & 3,25 & 48,86 & 54,11 & 18,70 & $0,023^{*}$ \\
\hline LH (mIU/ml) & 11,55 & 6,78 & 21,91 & 20,38 & 31,41 & 25,37 & 6,10 & $0,029 *$ \\
\hline $\begin{array}{l}\text { ESTRADIOL } \\
(\mathrm{pg} / \mathrm{ml})\end{array}$ & 83,52 & 57,20 & 57,07 & 22,98 & 35,60 & 6,73 & 30,20 & $0,024 *$ \\
\hline $\begin{array}{l}\text { PROLACTIN } \\
(\mathrm{ng} / \mathrm{ml})\end{array}$ & 29,55 & 12,19 & 58,69 & 47,90 & 81,60 & 68,90 & 32,30 & 0,343 \\
\hline TSH (uIU/ml) & 1,55 & 0,83 & 1,97 & 0,71 & 1,77 & 0,70 & 0,88 & 0,502 \\
\hline
\end{tabular}

$* p<0,05$

$S D$; standard deviation

Tablo VI: Menstrüasyon șekline göre hemodiyaliz hastalarının hematolojik ve biyokimyasal değerleri.

\begin{tabular}{|c|c|c|c|c|c|c|c|c|}
\hline & \multicolumn{2}{|l|}{$\begin{array}{l}\text { Regular } \\
(n=17)\end{array}$} & \multicolumn{2}{|c|}{$\begin{array}{l}\text { Oligomenorrhea } \\
(n=7)\end{array}$} & \multicolumn{2}{|c|}{$\begin{array}{l}\text { Amenorrhea } \\
(n=5)\end{array}$} & \multicolumn{2}{|c|}{$\begin{array}{l}\text { Menometrorrhagia } \\
(n=1)\end{array}$} \\
\hline & average \pm & SD & average \pm & $\mathrm{SD}$ & average \pm & $\mathrm{SD}$ & average & $\mathrm{p}$ value \\
\hline Hemoglobin (g/dL) & 10,12 & 1,14 & 10,24 & 1,43 & 10,50 & 0,60 & 10,10 & 0,810 \\
\hline Hematocrit (\%) & 30,78 & 3,58 & 31,29 & 4,27 & 32,42 & 2,05 & 31,10 & 0,521 \\
\hline Sodium (mmol/L) & 141,94 & 4,60 & 141,29 & 4,11 & 140,40 & 1,95 & 138,00 & 0,883 \\
\hline Potassium (mmol/L) & 4,44 & 0,92 & 4,41 & 0,36 & 5,74 & 0,62 & 5,50 & $0,015^{*}$ \\
\hline $\mathrm{BUN}(\mathrm{mg} / \mathrm{dl})$ & 160,53 & 47,23 & 137,71 & 30,37 & 162,00 & 48,68 & 171,00 & 0,439 \\
\hline Creatinine (mg/dl) & 9,61 & 2,03 & 9,10 & 1,89 & 9,46 & 0,57 & 13,30 & 0,730 \\
\hline Blood sugar (mg/dl) & 87,53 & 21,30 & 74,14 & 5,40 & 80,00 & 16,99 & 82,00 & 0,285 \\
\hline Calcium (mg/dl) & 9,28 & 1,32 & 10,11 & 0,68 & 9,52 & 1,06 & 10,70 & 0,181 \\
\hline Phosphorus (mg/dl) & 6,04 & 1,93 & 7,09 & 0,73 & 6,86 & 1,97 & 7,60 & 0,278 \\
\hline
\end{tabular}

$*_{p}<0,05$

SD; standard deviation

n; mumber of patients 
be thought to be parallel. If we look at pituitary-gonadal axis, studies have shown that LH levels were higher in premenopausal women with $\operatorname{CRF}(5,11,12,14)$. Both the metabolic clearance of LH decreases and production increases. The reply to the LHRH stimulation is delayed, but the responses might be normal or above normal. A limited number of studies suggest that in uremic female patients pulsatile LH secretion does not happen $^{(15,16)}$. Diurnal pulsatile LH release, preovulatuar high levels of LHRH and as a result LH surge necessary for ovulation could not be monitored in most of the patients $(17,18)$. While there are studies showing normal levels of FSH in uremic patients as in follicular and luteal phases of normal women ${ }^{(11)}$, there are other studies reported high levels of $\mathrm{FSH}^{(5,15)}$. In contrast to primary ovarian failure, the decrease in FSH / LH ratio indicates disorder of hypothalamic-pituitary regulation. Many factors that might lead to all these changes were investigated and are still being investigated(17). In accordance with the literature we found significantly higher levels of LH in hemodialysis patients compared to the control group $(\mathrm{p}<0.05)$. Moreover, even though FSH levels were higher in hemodialysis patients compared to the control group there was no statistically significant difference ( $\mathrm{p}>$ 0.05).

Even though estradiol levels in hemodialysis patients were detected lower than the control group this difference was not statistically significant ( $p>0.05)$. Similarly, Lim et al have found in their study including 24 patients that estradiol levels in the follicular phase were close to the values of the control group ${ }^{(19)}$. However, several studies including a large number of cases reported that estradiol levels are significantly lower compared to the control group $(14,15,20)$.

Another significant change in CRF patients is the hyperprolactinemia that disrupts ovarian function suppressing hypothalamus-pituitary-ovarian at many stages. Increase in prolactin levels in uremic patients since the $1970 \mathrm{~s}^{(21)}$. Sievertsen et al. ${ }^{(4)}$ found high plasma prolactin levels in $70 \%$ of the 73 hemodialysis patients. When the pharmacokinetics of prolactin in these patients were investigated, the extension of halflife was found associated with increased production of the pituitary along with longer clearance time from the circulation. Increased production rate, on the other hand, was shown to be associated with unresponsiveness of lactotrophic cells to the inhibitory effect of dopamine and was shown by longer duration of clearence of prolactin from the circulation during the dopamine infusion of 4 micrograms $/ \mathrm{kg}$ x minute ${ }^{(4)}$. In our study, we found high levels of prolactin in $22(73 \%)$ patients. In addition, when the patient and control groups were compared for the prolactin levels, we have seen that prolactin levels were 3-fold higher in hemodialysis patients. Even though prolactin levels were high in $73 \%$ of the patients, galactorrhea was found only in $13 \%$ of them. Similarly, in the literature galactorrhea was reported in $0 \%$ to $40 \%$ of hemodialysis patients (10).

Another issue questioned in patients with CRF is the cause of frequent amenorrhea.In our study, when the hormone profile of the group developed amenorrhea following dialysis was compared with the group that did not develop amenorrhea LH and prolactin levels were found higher in the group that developed amenorrhea, and even if the estradiol levels were lower there was no statistically significant difference between the groups $(p>0.05)$. However, one should not forget that this hormone levels reflect the last term of the status of patients after the hemodialysis which means for a long time (mean 6.28 years). Whereas the time amenorrhea seen is within the 12 months period right after the treatment is started. Today, amenorrhea persists only in 5 these 14 patients.

When the hemodialysis patients are divided into 4 groups as ones that have regular menstruation, amenorrheic, oligomenorrheic and menorrhagic, and compared in terms of hormone profiles, FSH and LH were statistically higher $(\mathrm{p}<0.05)$ in 5 patients that amenorrhea persisted compared to the other patient levels. While prolactin was higher in the regular group compared to oligomenorrhea group and higher in oligomenorrhea group compared to amenorrhea group this difference was not statistically significant $(p>0.05)$. In the amenorrhea group estradiol was lower than the other groups $(p<0.05)$. In a study performed on patients that did not have renal problems and have high levels of prolactin Topalski et al stated that irregularities increase as the prolactin levels increase ${ }^{(22)}$.

Matuszkiewicz-Rowinska et $\mathrm{al}^{(5)}$ found that LH and FSH levels were significantly higher in dialysis patients compared to the other groups. In addition, they have reported that patients with amenorrhea had significantly lower levels of serum estradiol (5). As it has been shown hyperprolactinemia is an important cause of menstrual 
disorders in hemodialysis patients.

In our study we used endometrial thickness measurements as an indicator of ovarian hormones. As it is known with the direct influence of ovarian hormones, estrogen and progesterone, cyclic changes in the endometrium occur as they are easily recognizable with the sonoraphy. In particular estrogen has trophic effect on the endometrium. During the proliferative phase the thickness of the normal endometrium varies between $4-8 \mathrm{~mm}^{(23)}$. In our study the endometrial thickness in the patient group was $6.52+2.13 \mathrm{~mm}$ and in the control group it was $6,58+1,59 \mathrm{~mm}(\mathrm{p}>0.05)$. Detection of amenorrhea only in $17 \%$ of hemodialysis patients and regular menstruation in $57 \%$ of them might be the reason of similar endometrial thickness in both groups. Another important reason for this condition in these cases is the long-term hemodialysis that all patients undergo and sufficient time for improvement of blood parameters. Perhaps if the cases were chosen among the patients in their first year of treatment, both hormone levels (prolactin, LH, FSH, estradiol) and endometrial thickness would have been quite different than the control group.

In conclusion, in accordance with the literature we showed that 13 (43\%) patients with CRF had menstrual disorders. In addition, 14 (47\%) of these patients developed amenorrhea following the hemodialysis program and amenorrhea continued in 5 (36\%) cases throughout the study. The most important cause of these menstrual disorders is increased levels of $\mathrm{LH}$ and prolactin due to impaired hypothalamic-pituitaryovarian axis. In CRF patients who had a short lifetimes in 1960s even if the most effective treatment is renal transplantation, hemodialysis is a successful form of treatment that prolongs the survival of patients and resolves the menstrual disorders by correcting the hypothalamic-pituitary-ovarian axis.

\section{REFERENCES}

1. Kadiroğlu AK, Şit D, Kayabaşı H, Yılmaz ME, Işıkoğlu B. Erkek hemodiyaliz hastalarında serum çinko seviyesi, hormonal profil ve seksüel disfonksiyon arasındaki ilişki Türk Nefroloji Diyaliz ve Transplantasyon Dergisi 2006;15(4): 218- 22.

2. Mujais SK, Sabatini S, Kurtzman NA. Pathophysiology of the uremic syndrome. In: Brenner MB, Rector FC, eds. The Kidney. Vol. 2. Philadelphia: WB Saunders, 1986: 1591- 8.
3. Niemczyk S, Matuszkiewicz-Rowifska J, Szamotulska K, Niemczyk L, Kulicki P, Ostrowski G, et al. Circadian profile of the prolactine concentration in the patients with end-stage renal failure. Pol Arch Med Wewn 2006; 116(6): 1137- 43.

4. Sievertsen GD, Lim VS, Nakawatase C, Frohman CA. Metabolic clearance and secretion of human prolactin in normal subjects and in patients with chronic renal failure. J Clin Endocrinol Metab 1980; 50: 846- 52.

5. Matuszkiewicz-Rowinska J, Skórzewska K, Radowicki S, Niemczyk S, Sokalski A, Przedlacki J, et al. Endometrial morphology and pituitary-gonadal axis dysfunction in women of reproductive age undergoing chronic haemodialysis--a multicentre study. Nephrol Dial Transplant 2004; 19(8): 2074- 7.

6. Holley JL, Schmidt RJ, Bender FH, Dumler F, Schiff M. Gynaecologic and reproductive issues in women on dialysis. Am J Kidney Dis 1997; 29: 685- 90.

7. Mastrogiacomo I, DeBesi L, Serafini E, Zussa S, Zucchetta P, Romagnoli GF, et al. Hyperprolactinemia and sexual disturbances among uremic women on hemodialysis. Nephron 1984; 37 : 195- 9 .

8. Özmen B, Taşkın S, Özcan E, Söylemez F. Kronik böbrek yetmezliğinde istenmeyen gebelik ve kontrasepsiyon: vaka sunumu ve literatürün özeti. TJOD Dergisi 2006; 3(2); 125 -

9. Goodwin NJ, Valente C, Hall JE, Freidman EA. Effects of uremia and chronic hemodialysis on reproductive cycle. Am J Obstet Gynecol 1968; 100: 528- 36.

10. Grünfeld JP, Kerr DN. The patient with failing renal function. In: Davison AM, Cameron JS, Grünfeld JP, Kerr DNS, Ritz E, Winearls CG, eds. Oxford Textbook of Clinical Nephrology. Vol. 2. New York: Oxford University Press, 1998: 1854- 82.

11. Morley JE, Distiller LA, Epstein S, Katz M, Gold C, Sagel $\mathrm{J}$, et al. Menstrual disturbences in chronic renal failure. Horm Metab Res 1979; 11(1): 68- 72.

12. Romero R, Abbassi H, Salah-Eddine A, Jersifi H, Samouh N, Moutabarrik A, et al. Chronic renal failure and pregnancy. Gynecol Obstet Fertil 2001; 29(2): 106- 15.

13. Kawashima R, Douchi T, Oki T, Yoshinaga M, Nagata Y. Menstrual disorders in patients undergoing chronic hemodialysis. J Obstet Gynaecol Res 1998; 24 (5):367- 73.

14. Montouvalos H, Metallinos C, Gouskos A, Makrygiannakis A. Sex hormones in women on hemodialysis. Int J Gynaecol Obstet 1984; 22: 367- 70 .

15. Ferraris JR, Domene HM, Escobar ME, Caletti MG, Ramirez JA, Rivarola MA. Hormonal profile in pubertal females with chronic renal failure:before and under haemodialysis and after renal transplantation. Acta Endocrinol (Copenh) 1987; 115(3): 289- 96. 
16. Mooradian AD, Morley JE. Endocrine dysfunction in chronic renal failure. Arch Intern Med 1984;144(2): 351- 3.

17. Grünfeld JP,Kerr DN. The patient with failing renal function. "Oxford Textbook of Clinical Nephrology" içinde, chapter 11, ed.: Davison A.M, Cameron J.S, Grünfeld J.P, Kerr D.N.S, Ritz E, Winearls CG. Second edition. Oxford University Press, New York, 1998: 1854- 82.

18. Swamy AP, Woolf PD, Cestero RVM. Hypothalamic pituitaryovarian axis in uremic women. J lab Clin Med 1979; 93: 106672 .

19. Lim VS, Henriquez C, Sievertsen G, Frohman LA. Ovarian function in chronic renal failure: evidence suggesting hypothalamic anovulation. Ann Intern Med 1980; 93(1): 21- 7.
20. Otieno MR, McLigeyo SO,Kigondu CS, Rogo KO. Menstrual disorders in patients with chronic renal failure. East Afr Med J 1993; 70(1): 6- 9.

21. Nagel TC, Freinkel N, Bell RH. Gynecomastia, prolactin and other peptide hormones in patients undergoing chronic hemodialysis. J Clin Endocrinol Metab 1973; 36(3): 428- 32.

22. Topalski-Fistes N, Bujas M, Maticki-Sekuliç M, Suvacarev S. Hyperprolactinemia and disorders of menstrual cycle. Med Pregl 1999; 52(3-5): 156- 61.

23. Yazıcıoğlu F. Endometriyal hastalıkların transvajinal sonorafisi. In: Fleischer AC, Manning FA, Jeanty P, eds. Obstetrik ve Jinekolojide Sonografi. Bölüm 43. A Simon and Schuster Company, 1996: 851- 69. 